\title{
The Reform of College English Teaching Based on Applied Talents Cultivation Under the Belt and Road Initiative
}

\author{
*Bing $\mathrm{He}$ \\ School of foreign language, Dalian Jiaotong University, DaLian, China \\ *Corresponding author e-mail: rachelhe2008@163.com
}

\begin{abstract}
Under the background of the belt and road initiative, College English plays a unique role as one of the courses to train applied talents. College English is a required course for college students to learn. With the continuous development of education reform and the progress of social development, the reform of College English Teaching under the application-oriented talent training mode needs to abandon the traditional teaching method, pay attention to the cultivation of students' ability, promote the development of students' body and mind, and improve students' learning efficiency, so as to provide useful for the society Applied talents. One belt, one road background, one belt, one road, is the key to the development of applied talents. The new challenges and problems of College English education are discussed, and the strategies for the reform of College English Education under the background of "one belt and one road" are discussed.

Keywords: one belt, one road, applied talents, College English, teaching reform
\end{abstract}

\section{INTRODUCTION}

Silk Road Economic Belt and one belt, one road ahead, were proposed by Xi Jinping, President of the Chinese delegation, during his visit to Central Asian and Southeast Asian countries in 2013. "One belt, one road" construction is the key to interconnection, including policy communication, facilities interconnection, trade flow, financing and common people's hearts. Combined with the historical one of "one belt, one road", we should clearly define the goal of talent training, deepen the reform of teaching mode, attach importance to the cultivation of applied talents and enhance the employability and competitiveness of graduates, so that students can have both professional knowledge and communication skills, and have the quality of innovation and entrepreneurship. How to improve the quality of College English classroom teaching, enhance college students' awareness of crosscultural communication, and cultivate high-quality, innovative and high-level management talents is imminent. [1] In this sense, it is of great practical significance to integrate the existing educational resources and effectively build a new mode of integration of innovation and entrepreneurship education and daily classroom teaching for students' employment and better planning of their future career. However, at this stage, College English teaching only pays attention to language teaching in personnel training, but despises the cultivation of students' application ability, resulting in high scores and low abilities of the students. Although they have solid theoretical knowledge of English, they can't skillfully use it in practical problems, and they can't integrate with other professional knowledge, so their comprehensive quality is not high. Therefore, one belt, one road, is the key to teaching reform. In order to cultivate applied talents, we should carry out teaching reform. While emphasizing language teaching, we should also cultivate students' language communication and communication ability, as well as the cultivation of humanistic quality, so that students can understand the knowledge of regional culture and international and domestic economic and trade, and further enhance their comprehensive ability. This paper mainly analyzes and studies the problems in College English teaching and the reform of College English Teaching under the applied talents training mode.

\section{THE INITIATIVE PUT FORWARD NEW REQUIREMENTS FOR UNIVERSITY EDUCATION}

\footnotetext{
"One belt, one road" is the abbreviation of the "Silk Road Economic Belt" and "twenty-first Century Maritime Silk Road". It relies on the existing bilateral and multilateral mechanisms between China and relevant countries, and relying on the existing and effective regional cooperation platform. "One belt, one road" brings China's plan for the world to win in the new era. Countries of different natures and stages of development have different specific strategic demands and priorities, but all countries want to achieve development and prosperity, which finds the greatest common denominator of common interests of all countries. How to connect the development plan of one country with the strategic design of other countries and realize the complementary advantages become the important premise for each country to achieve win-win and multi-win.
} 
With the proposal of one belt, one road initiative, new requirements for talents quality are put forward, that is, applied talents need both rich professional knowledge and international vision. This requires colleges and universities to pay attention to not only language teaching, improving students' language quality, but also the cultivation of their humanistic quality, so that they can understand the customs, cultures and international rules of different countries. Application talents also need to have strong communication ability, master the rules of language use, and then be proficient in communicating with foreign customers. In addition, they need to learn professional knowledge of management and marketing, so as to constantly enrich their management ability, so as to improve their comprehensive service level and adapt to the needs of the post. The ultimate goal of promoting the education of cultural integration lies in the students. Only when the students accept the concept of cultural collision and integration and dare to practice, can they say that the education has a practical effect. Therefore, teachers should take the concept of cultural integration as the carrier through their own classroom teaching and the teaching of College English knowledge, so as to cultivate the cultural communication awareness of college students. Encourage students to participate in various cultural exchange activities and College English competitions inside and outside the University, so as to improve their ability of fast learning, actively participate in various practical activities, and exercise their skills. The consciousness of innovation and entrepreneurship is cultivated in the practice of innovation and entrepreneurship. [2]

\section{THE BASIC PROBLEMS IN THE TRADINING MODE OF APPLIED TALENTS}

\subsection{Students' enthusiasm for participation is not high}

Most of the students are influenced by the exam oriented education mode in high school, lacking the ability of independent learning. In traditional English teaching, teachers take themselves as the main body of education, and the English education for students is indoctrinated and crammed. The channel for students to acquire English knowledge is relatively single. Although the network developed in the information age background, students can get more abundant learning resources in the network. By watching English teaching videos, pictures and other ways to change the English learning mode, students have a desire to explore English knowledge. Some college students have certain cognition and desire for innovation and entrepreneurship, and they are also willing to explore new theories and methods. However, due to some subjective and objective factors, they only stay in the theoretical aspect and do not really improve their innovation and entrepreneurship ability. Even if some students dare to practice, but because of their own knowledge and experience, the analysis of problems is simple and one-sided, it is difficult to solve the problems encountered in practice. There are also some college students who are not strong in innovation consciousness, dependent on teachers, lack of initiative and creativity. The classroom teaching should be exam oriented, the curriculum should pay attention to language knowledge, ignore language skills and application, and the curriculum for different professional English teaching is even less. The backwardness of teaching materials and the irrationality of curriculum design lead to the disconnection between the teaching content and the society and affect the improvement of students' English application ability. [3] In addition, in the process of College English teaching, teachers play a leading role, while students play the basic role of the main body, and the communication between teachers and students is still less, which causes a large number of students to be bored with English learning. Therefore, the difficulties encountered in the process of learning English, also can not actively consult the teacher, thus lasting, resulting in students' weakness in English. However, the learning of English majors and the improvement of their own abilities have a negative impact, which indirectly affects the students' neglect of the improvement of their own quality. [4]

\subsection{The deficiency of the teaching mode of training applied talents}

Today's social development needs people to provide a certain degree of depth for the teaching materials and the understanding level of English in Colleges and universities However, in the current development stage of talent training and the important stage of teaching reform, the traditional teaching methods adopted by teachers while teaching with teaching materials cannot be achieved if they cannot combine the learning characteristics of students and the current basic situation It meets the needs of social development. The teaching method has a direct impact on the teaching effect. As far as English Teaching in Colleges and universities is concerned, the teaching method is too single. Teachers are often the center of teaching. Students passively accept knowledge, lack the play of students' main position, and lack the cultivation of students' innovative thinking. This is not only related to the quality of College English teaching, but also to the enthusiasm of students. Most teachers still regard the dull teaching of textbook knowledge as the core of teaching, pay attention to the teaching of vocabulary and grammar, and neglect the training of students' listening and speaking ability. When the teaching and inculcation mode become the dominant mode, other new teaching modes can't really integrate into the classroom. The traditional teaching concept and single teaching mode will directly affect the improvement of students' English ability. In College English teaching, we pay too much attention to the passing rate of CET-4 and CET-6, and neglect to cultivate 
students' English language application ability. In the long run, students' enthusiasm, interest and attitude in learning English will also be affected.

Teachers' strength is an important guarantee to improve college English teaching level. Only with strong teachers' strength can we improve college English teaching level better. At present, the current situation of university teachers is that the age structure of teachers is too large, the scientific research ability is weak, the knowledge level of teachers is not high, and the teaching ability is uneven. All of these factors have seriously hindered the construction of English teachers in Applied Colleges and universities. In addition, heavy teaching tasks and trivial work affect the speed of teachers to improve their work ability and level, and influenced by economic ability, time, environment and other factors, teachers have less opportunities to go out for further study, can not understand the development of the international market in time, can not give students the most cutting-edge education in time, and even personal scientific research ability can not be obtained Effectively improve. In addition, with the popularization of education, the enrollment scale of colleges and universities continues to expand, and the teacher resources are increasingly tense. The existing English teachers are overloaded with work, and the new English teachers can't fill their places in time, which also directly affects the training effect of College English application talents. Combined with the current practice of social development and the basic requirements of application-oriented talent training mode, students lack a certain language environment and practice environment, which has a negative impact on the quality of their own ability. [5]

\section{THE REFORM OF COLLEGE ENGLISH TEACHING UNDER THE TRAINING MODE OF APPLIED TALENTS}

\subsection{Improve the professionalism of teachers and carry out professional teaching.}

In College English teaching, in order to cultivate application-oriented talents and promote the basic reform of teaching, it is necessary to give full play to the positive role of teachers. In the process of changing the concept of education, combined with the needs of social development, the content, basic measures, management methods and teaching materials of Education are studied accordingly, and the importance of English courses in talent training is emphasized, This needs to provide more services and personalized needs for students, and promote the cultivation of application-oriented talents. We should strengthen the construction of the teaching staff, strengthen the teaching staff, and better train the practical English talents. We should strive to build a professional team of high-quality teachers with exquisite business, full of vitality, noble ethics and reasonable structure. First of all, we should strengthen the training of the original teachers. On the one hand, we should cultivate the professional knowledge of English Teaching in Colleges and universities to improve the professional level of English teaching; on the other hand, we should train the College English education ideas to cultivate the innovative teaching ideas of teachers. Improving the overall teaching staff will help improve the English teaching level and cultivate more practical English talents for the society.

\subsection{The change of teaching concept}

Under the training mode of applied talents, College English teaching focuses on the cultivation of students' English application ability, while the traditional concept focuses on the passing rate of CET-4 and CET-6, which lacks the cultivation of students' English application ability. The College English teachers who aim at cultivating application-oriented talents must keep up with the development of the times, fully realize the deficiencies in teaching, renew the teaching concept in time, break through the brave new teaching mode and change the students into the teaching subjects unconsciously. Let students actively explore, while teachers only act as guides and participants in this process. When students become the main body of teaching, the teaching quality and the practical application ability of students will be significantly improved. Therefore, it is necessary to carry out teaching work in strict accordance with the principle of "student-oriented, employment oriented", so as to improve the effect of classroom teaching. In terms of teaching methods, teachers should adopt a variety of teaching modes, such as introducing English songs, English movies and other teaching materials, so that students can activate the classroom atmosphere by performing or scene reproduction and other ways. At the same time, teachers can, according to their own experience in learning English, impart boring single word memory to students through root method, homophony method, comics method and other interesting methods, so as to trigger Students' association can stimulate their interest in learning.

\subsection{Training and improvement of students' oral English ability}

In order to promote students' oral expression ability in English teaching, meet the needs of social and economic development, create a good oral platform for students, and constantly improve the application of students' comprehensive ability. Through the practice of students' oral English, students can play their own advantages in a good language environment and make up for their own weaknesses. At the same time, in the process of English knowledge and learning, students can learn and enrich the characteristics of English through oral English. 


\subsection{Establishing the evaluation system of College English Teaching for the cultivation of Applied Innovative Talents}

The CET-4 and CET-6 can still serve the curriculum system of College English. The design principle is to use the research results of Applied Linguistics to determine the test objectives and the test concept according to the requirements of College English curriculum. To a certain extent, it is helpful for the university to establish a scientific, overall and horizontal College English curriculum assessment method. But at the same time, we should pay attention to "process evaluation". In order to observe, evaluate and supervise students' learning process and promote students' effective learning, the process assessment can take many forms, such as classroom activity record, extracurricular practice result display, online self-study record, learning file record, interview and discussion.

It is also necessary to evaluate the teaching quality of College English teachers. In order to improve the objectivity of teaching evaluation and the authenticity of data, each student can be required to participate in the evaluation anonymously. At the same time, teachers can only see students' evaluation of themselves, not students' performance and other teachers' evaluation results. Therefore, students' evaluation of teaching can not only improve teachers' teaching work in an all-round way, but also improve teachers' teaching quality. We should also establish a mechanism of mutual listening and evaluation among teachers. Through the process of mutual listening and evaluation, we can provide information feedback for teachers' teaching, evaluate and exchange teaching, promote the improvement of teaching quality and teaching level, and realize the common development of teachers on both sides of evaluation. So that teachers can understand their own teaching level and teaching ability, give full play to their own advantages, establish the concept of lifelong learning, and constantly improve themselves. To make teachers keep a positive and active attitude to do a good job in teaching and optimize the teaching staff is conducive to the scientific and reasonable evaluation of the professional level of teachers and the overall improvement of the quality of teachers.

\section{CONCLUSION}

One belt, one road, is China's new one of globalization. One belt, one road country is inevitable. In the new development and new situation, the country needs a large number of application-oriented talents with speculative thinking, critical spirit, the courage to innovate and the courage to take on important tasks. As the purpose of College English teaching is to cultivate applicationoriented talents, we should try our best to explore the reform measures of College English teaching based on the application-oriented talents training mode, in order to lay a solid foundation for students' language, enable students to master the ability of foreign exchange, improve their own language and cultural literacy, promote the formation of students' personalized learning methods and the development of their independent learning ability, and enhance students' awareness of In order to cultivate practical English talents who can meet the needs of the development and changes of the society, we should do something in the adaptability, practice, creation, employment and Entrepreneurship of the social market.

\section{REFERENCES}

[1] Hao Qian. One belt, one road background, the strategy of cultivating students' innovative and entrepreneurial consciousness [J] Journal of Gansu Normal University, 2018,23 (3): 83-87.

[2] Liu Kexin, Liang Na. Research on the construction of College English teaching evaluation system for the training of first-class applied innovative talents. [J]. Overseas English, 2019,24 (12): 142-144

[3] Zhang Lihua. The reform of College English Teaching under the application-oriented personnel training mode. Overseas English, 2019,20 (10): 181182

[4] Jiang Yingying, Ji Zhemin. Research on the reform of College English Teaching under the mode of Applied Talents Training [J] Journal of Jilin Education College, 2015.02(31):105-106.

[5] Han Shuang. Research on College English teaching reform from the perspective of applied talents training. Overseas English, 2020,2 (1): 165-166 